Editorial

\title{
IAO Systematic Review Award 2021
}

\author{
Geraldo Pereira Jotz ${ }^{1}{ }^{\circledR}$ Aline Gomes Bittencourt ${ }^{2}{ }^{\circledR}$ \\ 1 Dean of Innovation and Institutional Affairs, Universidade Federal do \\ Rio Grande do Sul (UFRGS), Porto Alegre, RS, Brazil \\ 2 ENT, Department of Medicine, Universidade Federal do Maranhão \\ (UFMA), São Luís, MA, Brazil \\ 3 Department of Otorhinolaryngology, Universidade de São Paulo, \\ São Paulo, SP, Brazil
}

Adilson Marcos Montefusco 3

Int Arch Otorhinolaryngol 2022;26(1):e3-e4.

The IAO Systematic Review Award is awarded every year to the best articles in systematic review, including meta-analyses, published in the International Archives of Otorhinolaryngology (IAO) that seeks to highlight articles that form the foundations and concepts of universal knowledge. ${ }^{1}$ In 2021, it was awarded to the three best systematic and/or literature reviews that were published in the journal in the year 2020 (-Table 1) $)^{2-4}$ This award was established to encourage the submission of high-quality systematic review articles.

Systematic review is a method of evidence synthesis that critically assesses and interprets all relevant research available regarding a particular issue, area of knowledge, or

Table 1 Description of the best studies IAO Systematic Review Award 2021

\begin{tabular}{|c|c|c|c|c|c|c|}
\hline Place & Author, year & Title & Country & Objective & Issue & DOI \\
\hline $1^{\text {st }}$ & Gore, $^{2} 2020$ & $\begin{array}{l}\text { Lemierre } \\
\text { Syndrome: } \\
\text { A Meta-analysis }\end{array}$ & United States & $\begin{array}{l}\text { 1) To perform a } \\
\text { meta-analysis on } \\
\text { outcomes and } \\
\text { treatment of } \\
\text { Lemierre } \\
\text { syndrome; and 2) } \\
\text { to evaluate the ef- } \\
\text { fect of anticoagula- } \\
\text { tion in Lemierre } \\
\text { syndrome on vessel } \\
\text { recanalization } \\
\text { and on mortality. }\end{array}$ & $\begin{array}{l}\text { 24(3): } \\
\text { e379-e385. }\end{array}$ & $\begin{array}{l}10.1055 / \mathrm{s}-0039- \\
3402433\end{array}$ \\
\hline $2^{\text {nd }}$ & $\begin{array}{l}\text { Parilli-Troconis } \\
\text { et al., }{ }^{3} 2020\end{array}$ & $\begin{array}{l}\text { COVID-19 Infection } \\
\text { and Its } \\
\text { Influence in } \\
\text { Otorhinolaryngology- } \\
\text { Head } \\
\text { and Neck Surgery }\end{array}$ & $\begin{array}{l}\text { Spain, Venezuela, } \\
\text { United States }\end{array}$ & $\begin{array}{l}\text { This review aims to } \\
\text { summarize the } \\
\text { available diagnostic } \\
\text { tools and current } \\
\text { guidelines to safely } \\
\text { assist patients while } \\
\text { limiting the } \\
\text { exposure of } \\
\text { otolaryngologists } \\
\text { during this } \\
\text { pandemic. }\end{array}$ & $\begin{array}{l}\text { 24(4): } \\
\text { e527-e534. }\end{array}$ & $\begin{array}{l}10.1055 / \mathrm{s}-0040- \\
1715586\end{array}$ \\
\hline $3^{\text {rd }}$ & $\begin{array}{l}\text { Hojaij et al., } \\
2020\end{array}$ & $\begin{array}{l}\text { Head and Neck } \\
\text { Practice } \\
\text { in the COVID-19 }\end{array}$ & Brazil & $\begin{array}{l}\text { To provide an easy } \\
\text { access to and a } \\
\text { trustful review of }\end{array}$ & $\begin{array}{l}\text { 24(4): } \\
\text { e518-e526. }\end{array}$ & $\begin{array}{l}10.1055 / \mathrm{s}-0040- \\
1715506\end{array}$ \\
\hline
\end{tabular}

(Continued)

Address for correspondence Geraldo Pereira Jotz, MD, PhD, Rua Sarmento Leite, 500, Prédio do ICBS, Porto Alegre, RS, 90050170 , Brazil (e-mail: iaorl@iaorl.org).
DOI https://doi.org/ $10.1055 / \mathrm{s}-0042-1742354$. ISSN 1809-9777. (c) 2022. Fundação Otorrinolaringologia. All rights reserved.

This is an open access article published by Thieme under the terms of the Creative Commons Attribution-NonDerivative-NonCommercial-License, permitting copying and reproduction so long as the original work is given appropriate credit. Contents may not be used for commercial purposes, or adapted, remixed, transformed or built upon. (https://creativecommons.org/ licenses/by-nc-nd/4.0/)

Thieme Revinter Publicações Ltda., Rua do Matoso 170, Rio de Janeiro, RJ, CEP 20270-135, Brazil 
Table 1 (Continued)

\begin{tabular}{|l|l|l|l|l|l|l|}
\hline Place & Author, year & Title & Country & Objective & Issue & DOI \\
\hline & & $\begin{array}{l}\text { Pandemics Today: } \\
\text { A Rapid Systematic } \\
\text { Review }\end{array}$ & & $\begin{array}{l}\text { the main aspects } \\
\text { that have changed } \\
\text { in the head and } \\
\text { neck surgery and } \\
\text { otorhinolaryngology } \\
\text { practice due to the } \\
\text { COVID-19 } \\
\text { pandemic. }\end{array}$ & & \\
& & & & & & \\
\end{tabular}

phenomenon of interest. Statistical methods (meta-analysis) are usually included in the analysis and synthesis of results, allowing the increase of the sample size and accuracy of the assessed outcomes. ${ }^{5}$ Systematic reviews and meta-analysis are at the top of the pyramid of evidence. They provide the highest level of evidence to verify the effectiveness of interventions, help health professionals to stay up to date with latest developments, provide evidence for decision making, enable evaluation of the risks and benefits of interventions, provide inputs for assistance guidelines development, and provide information on prior studies for potential funding sources for new research. ${ }^{1}$ We suggest the use of guidelines for elaboration and conduction of systematic review using well-defined and explicit methods aimed at minimizing biases. ${ }^{5,6}$

The competing works must be published in editions 1 to 4 in the year before the award. The rules for manuscript submission are available at http://www.thieme.com/iao. The judging commission, comprising of members of the editorial board, will be coordinated by the chief editor of this journal. Articles will be judged based on scientific merit, including originality, consistency, significance, and impact. The winning authors and co-authors will receive certificates for their work. The best systematic reviews will be announced in the last edition of each volume of the following publication year, thus providing enough time to accumulate citations needed for analyses.

With this effort, we wish to honor and show our appreciation to the deserving authors, and encourage new talents in international otorhinolaryngological research with a commitment to stimulate education and technological development through research and training.
We are pleased to announce the studies IAO Systematic Review Award 2021, as shown in -Table 1.

Conflict of Interests

The authors have none to declare.

\section{References}

1 Jotz GP, Bittencourt AG, Montefusco AM. IAO Systematic Review Award 2020. Int Arch Otorhinolaryngol 2020;24(04):e397-e398. Doi: $10.1055 / \mathrm{s}-0040-1718748$

2 Gore MR. Lemierre Syndrome: A Meta-analysis. Int Arch Otorhinolaryngol 2020;24(03):e379-e385. Doi: 10.1055/s-00393402433

3 Parilli-Troconis D, Baptista P, Marcano-Lozada M, Goncalves S, Shahal D, Chiossone-Kerdel JA. COVID-19 Infection and Its Influence in Otorhinolaryngology-Head and Neck Surgery. Int Arch Otorhinolaryngol 2020;24(04):e527-e534. Doi: 10.1055/s-00401715586

4 Hojaij FC, Chinelatto LA, Boog GHP, Kasmirski JA, Lopes JVZ, Medeiros VMB. Head and Neck Practice in the COVID-19 Pandemics Today: A Rapid Systematic Review. Int Arch Otorhinolaryngol 2020;24(04):e518-e526. Doi: 10.1055/s-0040-1715506

5 Ministério da Saúde (BR) Diretrizes Metodológicas: Elaboração de Revisão Sistemática e Metanálise de Ensaios Clínicos Randomizados [Methodological guideline: development of systematic review and meta-analysis of randomized clinical trials] [Internet] Brasilia - DF: Ministério da Saúde; 2015 [cited 2020 Sep 22]. 92 p. Available from: http://bvsms.saude.gov.br/bvs/publicacoes/ diretrizes_metodologicas_ensaio_clinico_randomizado_1edicao. pdf

6 Higgins JPT, Thomas J, Chandler J, et al., Eds. Cochrane Handbook for Systematic Reviews of Interventions version 6.1 (updated September 2020) [Internet]. Cochrane; 2020 [cited 2020 Sep 22]. Available from www.training.cochrane.org/handbook 